\title{
Degradation of a Fungicide, Mepanipyrim, in Soils
}

\author{
Mitsumasa IKeda, Yuzuru Asano, Yoshihiro MAeda and Yoshio Yusa \\ Life Science Research Institute, Kumiai Chemical Industry Co., Ltd., Tamari, Kakegawa 436-0011, Japan
}

(Received February 17, 1997 ; Accepted November 8, 1997)

\begin{abstract}
The degradation of mepanipyrim [ $N$-(4-methyl-6-prop-1-ynylpyrimidin-2-yl)aniline] in two soils was studied under the laboratory conditions, using ${ }^{14} \mathrm{C}$-preparations labeled separately in the pyrimidine and the benzene rings. The half-lives of the parent compound in upland soils were 13 days and 3 months. The compound was degraded via pathways including elimination of the phenyl group, hydroxylation of the propynyl moiety, and hydroxylation at the benzene ring. The main degradation route was elimination of the phenyl group. The large portion of the resultant products was probably incorporated into the bound residues and a small part was further degraded to ${ }^{14} \mathrm{CO}_{2}$. ${ }^{14} \mathrm{C}$-Carbon dioxide evolved in the soils treated with both ${ }^{14} \mathrm{C}$-preparations. Under the flooded condition mepanipyrim was degraded rapidly, and a larger amount of bound residues was formed compared with the upland condition. The main degradation route in the flooded condition was the serial changes of the propynyl moiety. Mepanipyrim was hardly degraded in the sterilized soils under the upland condition, suggesting that it was microbially degraded in the soils. It is also observed that mepanipyrim was slowly degraded even in the sterilized soils under the flooded condition, suggesting that non-biological degradation also was involved in causing the decrease of mepanipyrim.
\end{abstract}

\section{INTRODUCTION}

Mepanipyrim, $N$-(4-methyl-6-prop-1-ynylpyrimidin-2-yl)aniline (Fig. 1), is a novel fungicide developed for the control of gray mold, scab, and brown rot caused by Botrytis cinerea, Venturia inaequaris and Monilinia fructicola, respectively. ${ }^{1,2)}$ For the development of a new pesticide, it is necessary to elucidate the environmental fate of the pesticide. In this report, the degradation of mepanipyrim is studied in two soils under the upland and the flooded conditions with emphasis on the degradation pathways. ${ }^{3)}$

\section{MATERIALS AND METHODS}

\section{Chemicals}

Samples of mepanipyrim labeled with ${ }^{14} \mathrm{C}$ separately at the $\mathrm{C}(4)$ position of the pyrimidine ring $\left(\left[\mathrm{Py}_{-}{ }^{14} \mathrm{C}\right]\right.$ mepanipyrim), and in the benzene ring $\left(\left[\mathrm{Be}-{ }^{14} \mathrm{C}\right]\right.$ mepanipyrim) were synthesized by Daiichi Pure Chemicals Co., Ltd. The specific radioactivity was $726 \mathrm{MBq} /$ mmol for $\left[\mathrm{Py}-{ }^{14} \mathrm{C}\right]$ mepanipyrim and $562 \mathrm{MBq} / \mathrm{mmol}$ for $\left[\mathrm{Be}-{ }^{14} \mathrm{C}\right]$ mepanipyrim. Each radiochemical purity was more than $99 \%$ as measured by silica gel thin-layer chromatography (TLC) with solvent systems A and B shown in Table 1.

Unlabeled mepanipyrim and compounds, shown in Table 1, were synthesized by K-I Chemical Research
Institute Co., Ltd., for reference purpose.

\section{2. $T L C$}

The extracts from the soils were spotted on precoated silica gel $60 \mathrm{~F}_{254}$ chromatoplates $(20 \times 20 \mathrm{~cm}, 0.25 \mathrm{~mm}$ thick, E. Merck), which were developed in two sets of two dimensions, first with the solvent system $A$ and secondly with the solvent system B or C. Radioactive spots on TLC plates were detected by autoradiography using Fuji X-ray films, and unlabeled authentic compounds by a Manaslu-light lamp (Manaslu Chem. Co., Ltd.).

\section{Soils}

Two kinds of the soil were collected from upland fields in Kikugawa (Kumiai Chemical Industry Co., Ltd., Shizuoka-Pref.) and Ushiku (Japan Plant Protection Association, Ibaraki-Pref.). Each soil was passed through a 2-mm sieve before use. Their properties are listed in Table 2.

\section{Degradation Study in Soils \\ 4.1 Soil treatment}

Each soil equivalent to $30 \mathrm{~g}$ on an oven-dry weight basis was taken into a $100 \mathrm{ml}$ Erlenmeyer flask, and added with water up to $50 \%$ of the maximum water holding capacity for the upland condition, or up to 1.2 
<smiles>CC#Cc1cc(C)nc(Nc2ccccc2)n1</smiles>

Fig. 1 Structure of mepanipyrim.

$\mathrm{cm}$ depth for the flooded condition. Mouth of the flask was covered with aluminum foil. After the soil sample was preincubated at $28^{\circ} \mathrm{C}$ in the dark for a week, $\left[\right.$ Py $-{ }^{14} \mathrm{C}$ ] mepanipyrim $(12.17 \mu \mathrm{g}$ in $0.4 \mathrm{ml}$ of acetone) was applied to them $(0.41 \mathrm{ppm}$ to dry soil) and mixed well. Sterilized soil samples, autoclaved at $120^{\circ} \mathrm{C}$ for 30 min intermittently twice every other day, were treated with the compound in the same procedure as above. The flask was plugged with a cotton stopper. In the study of $\left[\mathrm{Be}-{ }^{14} \mathrm{C}\right]$ mepanipyrim degradation, $\left[\mathrm{Be}-{ }^{-14} \mathrm{C}\right]$ mepanipyrim $(158.21 \mu \mathrm{g}$ in $0.7 \mathrm{ml}$ of acetone) was applied to the preincubated soil $(60 \mathrm{~g}$ on a oven-dry weight basis) to a concentration of $2.64 \mathrm{ppm}$.

For trapping ${ }^{14} \mathrm{CO}_{2}$ evolved from the soils except the sterilized soils, a vial ( $15 \mathrm{~mm}$ i.d.) containing $5 \mathrm{ml}$ of $3 \mathrm{~N}$
$\mathrm{NaOH}$ aqueous solution was strung in each flask. The alkaline solution was renewed every 10 days. The soil moisture was adjusted periodically to its original level by adding distilled water. The flask was incubated at $28^{\circ} \mathrm{C}$ in a dark incubation chamber for 180 days.

\subsection{Extraction and fractionation of soil samples}

At designated intervals, the incubated soils were refluxed with $150 \mathrm{ml}$ of a solvent mixture of acetone and water $(4+1)$ for the upland condition or $120 \mathrm{ml}$ of acetone for flooded one in a $75^{\circ} \mathrm{C}$ water bath for $1 \mathrm{hr}$. The content was filtered through suction. The residue was rinsed with $70 \mathrm{ml}$ of acetone and filtered again by the same procedure. The filtrates were combined and concentrated to about $50 \mathrm{ml}$ by a rotary evaporator. The residual aqueous phase was extracted twice with $40 \mathrm{ml}$ of dichloromethane. The extract combined was dried with anhydrous $\mathrm{Na}_{2} \mathrm{SO}_{4}$. The soil sample was divided into three fractions by the above procedures: the organosoluble fraction, the water-soluble fraction and soil bound residues. Each of the organo-soluble and watersoluble fractions was radioassayed and analyzed by TLC. Recoveries of mepanipyrim in this procedure were $\mathbf{9 4 - 9 7 \%}$ in both soils, immediately after application

Table 1 Thin-layer chromatographic data of authentic compounds.

\begin{tabular}{llccc}
\hline \multirow{2}{*}{$\begin{array}{c}\text { Authentic } \\
\text { compound }\end{array}$} & \multicolumn{1}{c}{ Chemical name } & \multicolumn{3}{c}{$R f$ values in solvent systems ${ }^{\mathrm{a})}$} \\
\cline { 3 - 5 } & & $\mathrm{A}$ & $\mathrm{B}$ & $\mathrm{C}$ \\
\hline Mepanipyrim & $N$-(4-methyl-6-prop-1-ynylpyrimidin-2-yl)aniline & 0.55 & 0.40 & 0.76 \\
M-5 & 2-anilino-4,6-dimethylpyrimidine & 0.50 & 0.24 & 0.72 \\
M-6 & 1-(2-anilino-6-methylpyrimidin-4-yl)-2-propanone & 0.45 & 0.15 & 0.71 \\
M-1 & 4-[4-methyl-6-(1-propynyl)pyrimidin-2-ylamino]phenol & 0.40 & 0.03 & 0.69 \\
M-4 & 3-(2-anilino-6-methylpyrimidin-4-yl)-2-propyn-1-ol & 0.36 & 0.03 & 0.67 \\
M-31 & 1-(2-anilino-6-methylpyrimidin-4-yl)-2-propanol & 0.29 & 0.08 & 0.61 \\
M-15 & (2-anilino-6-methylpyrimidin-4-yl)methanol & 0.28 & 0.05 & 0.59 \\
M-39 & 1-(2-anilino-6-methylpyrimidin-4-yl)-1,2-propanediol & 0.13 & 0.03 & 0.48 \\
M-41 & 4-methyl-6-(1-propynyl)pyrimidin-2-ylamine & 0.10 & 0.06 & 0.37 \\
\hline
\end{tabular}

a) Solvent systems : A, ethyl acetate : benzene $(1: 1, \mathrm{v} / \mathrm{v}) ; \mathrm{B}$, chloroform ; C, acetonitrile : benzene $(2: 1, \mathrm{v} / \mathrm{v})$.

Table 2 Properties of the test soils.

(Oven-dry soil basis)

\begin{tabular}{lcc}
\hline & \multicolumn{2}{c}{ Soil source } \\
\cline { 2 - 3 } & Kikugawa & Ushiku \\
\hline Soil origin & Alluvial & Volcanic ash \\
Soil texture & Light clay & Loam \\
Particle-size distribution (\%) & & \\
$\quad$ Coarse sand & 1.7 & 40.1 \\
$\quad$ Fine sand & 41.1 & 21.1 \\
Silt & 31.2 & 33.4 \\
Clay & 26.0 & 5.4 \\
Total carbon (\%) & 1.15 & 5.63 \\
Total nitrogen (\%) & 0.089 & 0.521 \\
Cation exchange capacity (me/100 g) & 13.6 & 22.9 \\
pH (H ${ }_{2}$ ) & 5.72 & 4.69 \\
Maximum water-holding capacity (\%) & 59.0 & 118.3 \\
\hline
\end{tabular}


of $0.41 \mathrm{ppm}\left[\mathrm{Py}-{ }^{14} \mathrm{C}\right]$ mepanipyrim.

The soil bound residues were also submitted to radioassay. Furthermore, a portion of samples 40 days after application was fractionated into fulvic acid, humic acid and humin fractions by alkaline extraction. ${ }^{4}$ The fulvic acid fraction was extracted with dichloromethane, which was analyzed by TLC after concentrated.

In the $\left[\mathrm{Be}^{-14} \mathrm{C}\right]$ mepanipyrim study, the same method except that a 1.5 -fold volume of all solvents was used for extraction and fractionation procedures.

\subsection{Identification of degradation products}

Degradation products were identified by co-TLC with authentic compounds.

\section{Radioassay}

The radioactivity of the solutions were measured with a Packard Tri-Carb 300C Liquid Scintillation Spectrometer (LSC), using $10 \mathrm{ml}$ of Scintiblender III (Nakarai Chemicals, Ltd.). After scraped off, radioactive spots on chromatoplates were analyzed by the same procedure as above. Radioactivity in soil bound residues was quantified by wet combustion of $300 \mathrm{mg}$ sample with the Van Slyke and Folch medium, ${ }^{5)}$ followed by LSC measurement. All results obtained with wet combustion were not corrected using recovery. To determine ${ }^{14} \mathrm{CO}_{2}$ evolved from soil $1 \mathrm{ml}$ of $1 \mathrm{~N} \mathrm{BaCl}_{2}$ solution was added to $5 \mathrm{ml}$ of the trap solution, and the mixture was centrifuged to radioassay the supernatant solution.

\section{RESULTS}

\section{Degradation in Soils}

The dissipation profiles of $\left[\mathrm{Py}-{ }^{14} \mathrm{C}\right]$ mepanipyrim in two kinds of the soil under the upland and the flooded conditions are shown in Fig. 2. The half-life of degradation in each soil was calculated by the graphical interpretation. The following results were obtained, 13 days for Kikugawa soil under the upland, 10 days for Kikugawa soil under the flooded, 3 months for Ushiku soil under the upland and 15 days for Ushiku soil under the flooded conditions. $\left[\mathrm{Py}^{-14} \mathrm{C}\right]$ Mepanipyrim was degraded more rapidly under the flooded condition than the upland one. Although the difference in the degradation rate was observed in both conditions, it was very small in Kikugawa soil, compared with Ushiku soil. $\left[\mathrm{Py}^{14} \mathrm{C}\right]$ Mepanipyrim decreased to 7 and $12 \%$ of the applied dosage in Kikugawa and Ushiku soils, respectively, 120 days later. The dissipation of $\left[\mathrm{Py}_{-}{ }^{14} \mathrm{C}\right]$ mepanipyrim in Kikugawa soil under the sterilized conditions is shown in Fig. 3. The disappearance of $\left[\mathrm{Py}-{ }^{14} \mathrm{C}\right]$ mepanipyrim was retarded under the conditions, compared with unsterilized ones (Fig. 2). Under the flooded condition $\left[\mathrm{Py}_{-}{ }^{14} \mathrm{C}\right]$ mepanipyrim was degraded slowly to $53 \%$ of the applied dosage, 120 days after the application.

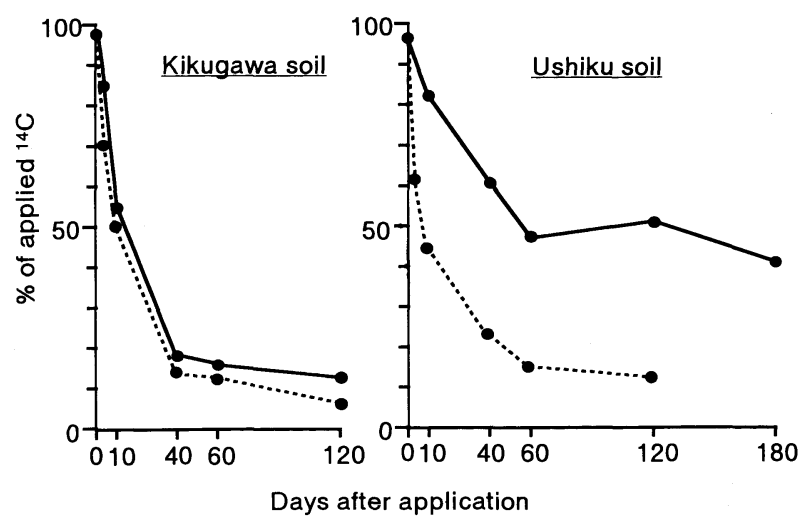

Fig. 2 Dissipation of mepanipyrim in Kikugawa and Ushiku soils.

- : upland condition, $\cdots \cdots \cdot$ : flooded condition.

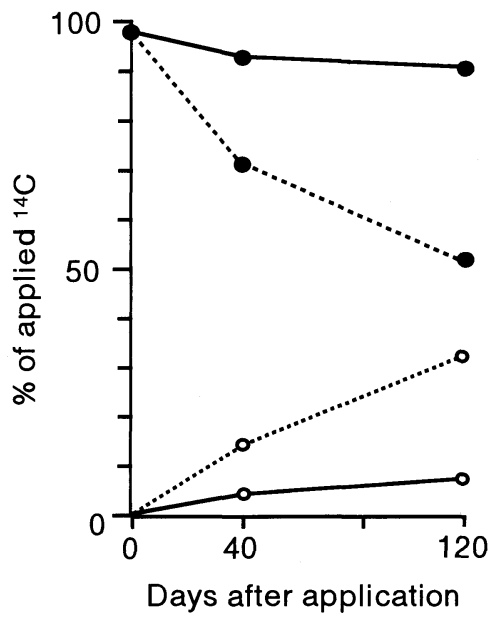

Fig. 3 Changes in mepanipyrim ( $\bullet$ ) and bound ${ }^{14} \mathrm{C}(O)$ in Kikugawa soil under sterilized conditions.

- : upland condition, $\cdots \cdots \cdot$ : flooded condition.

\section{Degradation Products of $\left[P y-{ }^{14} C\right]$ Mepanipyrim in Soils}

The amounts of $\left[\mathrm{Py}_{-}{ }^{14} \mathrm{C}\right]$ mepanipyrim and its degradation products in the soils under the upland and the flooded conditions are listed in Tables 3 and 4, respectively.

Under the upland condition, most of the radioactivity in the extracts was derived from unchanged mepanipyrim. M-41 was the major degradation product which increased up to 3.9 and $2.2 \%$ of the applied dosage in Kikugawa soil 10 days later and Ushiku soil 120 days later, respectively. M-1 and M-4 were minor degradation products at the early stage, which did not reach $0.2 \%$ of the applied dosage. More than 7 and 10 other degradation products were detected in the organo-soluble and the water-soluble fractions by TLC analysis, respectively. Although they were not identified, they amounted in total to less than $1 \%$ of the applied dosage. Radiocarbon trapped in the alkaline solution was considered 
Table 3 Changes in amounts of $\left[\mathrm{Py}^{-14} \mathrm{C}\right]$ mepanipyrim and its degradation products in Kikugawa and Ushiku soils under the upland condition.

\begin{tabular}{|c|c|c|c|c|c|c|c|c|c|c|}
\hline \multirow{4}{*}{$\begin{array}{c}\text { Fraction } \\
\text { and } \\
\text { degradation } \\
\text { product }\end{array}$} & \multicolumn{10}{|c|}{$\%$ of applied ${ }^{14} \mathrm{C}$} \\
\hline & \multicolumn{5}{|c|}{ Kikugawa soil } & \multicolumn{5}{|c|}{ Ushiku soil } \\
\hline & \multicolumn{5}{|c|}{ days after application } & \multicolumn{5}{|c|}{ days after application } \\
\hline & 5 & 10 & 40 & 60 & 120 & 10 & 40 & 60 & 120 & 180 \\
\hline Organo-soluble & 86.5 & 62.4 & 27.0 & 22.9 & 19.6 & 83.8 & 64.8 & 51.1 & 55.6 & 45.6 \\
\hline Mepanipyrim & 85.0 & 54.6 & 19.5 & 16.2 & 12.9 & 82.3 & 62.1 & 48.3 & 51.8 & 41.6 \\
\hline M-1 & -a) & 0.2 & - & - & - & - & - & - & - & - \\
\hline M-4 & 0.2 & - & - & - & - & 0.2 & 0.2 & 0.1 & - & - \\
\hline M-41 & 0.4 & 8.9 & 3.1 & 2.9 & 2.1 & 0.5 & 1.5 & 1.6 & 2.2 & 2.0 \\
\hline Others & 0.7 & 2.9 & 3.5 & 2.9 & 3.5 & 0.6 & 0.9 & 0.9 & 1.3 & 1.5 \\
\hline Origin & 0.2 & 0.7 & 0.9 & 0.9 & 1.0 & 0.2 & 0.2 & 0.2 & 0.3 & 0.6 \\
\hline Water-soluble & 1.7 & 2.6 & 4.3 & 4.1 & 2.9 & 1.3 & 7.5 & 3.6 & 0.9 & 0.8 \\
\hline${ }^{14} \mathrm{CO}_{2}$ & 0.2 & 0.6 & 3.7 & 5.6 & 8.0 & 0.1 & 0.5 & 0.8 & 1.6 & 2.3 \\
\hline Bound ${ }^{14} \mathrm{C}$ & 10.4 & 31.0 & 36.8 & 39.6 & 56.1 & 9.3 & 21.0 & 26.0 & 33.5 & 40.7 \\
\hline Total & 98.8 & 96.6 & 71.8 & 72.2 & 86.7 & 94.4 & 93.8 & 81.4 & 91.6 & 89.4 \\
\hline
\end{tabular}

a) $-:<0.1 \%$.

Table 4 Changes in amounts of $\left[\mathrm{Py}^{-14} \mathrm{C}\right]$ mepanipyrim and its degradation products in Kikugawa and Ushiku soils under the flooded condition.

\begin{tabular}{|c|c|c|c|c|c|c|c|c|c|c|}
\hline \multirow{4}{*}{$\begin{array}{l}\text { Fraction } \\
\text { and } \\
\text { degradation } \\
\text { product }\end{array}$} & \multicolumn{10}{|c|}{ \% of applied ${ }^{14} \mathrm{C}$} \\
\hline & \multicolumn{5}{|c|}{ Kikugawa soil } & \multicolumn{5}{|c|}{ Ushiku soil } \\
\hline & \multicolumn{5}{|c|}{ days after application } & \multicolumn{5}{|c|}{ days after application } \\
\hline & 5 & 10 & 40 & 60 & 120 & 5 & 10 & 40 & 60 & 120 \\
\hline Organo-soluble & 71.1 & 52.2 & 18.6 & 18.6 & 11.5 & 63.1 & 45.4 & 25.7 & 21.7 & 24.6 \\
\hline Mepanipyrim & 69.9 & 49.7 & 13.4 & 12.6 & 7.0 & 62.4 & 44.8 & 24.0 & 15.3 & 12.2 \\
\hline M-1 & 0.3 & 0.4 & 0.2 & -a) & - & 0.1 & - & - & - & - \\
\hline M-4 & - & - & - & - & - & 0.1 & 0.1 & - & - & - \\
\hline M-41 & - & 0.1 & 0.1 & 0.1 & - & 0.2 & 0.1 & - & - & - \\
\hline M-6 & 0.2 & 0.4 & 0.3 & 0.4 & 0.6 & - & - & 0.1 & 0.5 & 2.2 \\
\hline M-31 & 0.1 & 0.4 & 2.9 & 3.8 & 2.4 & - & - & 0.4 & 3.2 & 6.8 \\
\hline M-5 & - & 0.2 & 0.3 & 0.3 & 0.3 & - & - & 0.1 & 0.3 & 0.7 \\
\hline Others & 0.5 & 0.5 & 0.7 & 0.8 & 0.7 & 0.3 & 0.3 & 0.6 & 1.3 & 2.1 \\
\hline Origin & 0.2 & 0.7 & 0.8 & 0.6 & 0.5 & 0.1 & 0.1 & 0.5 & 1.1 & 0.6 \\
\hline Water-soluble & 0.3 & 0.7 & 1.0 & 1.9 & 0.8 & 0.4 & 0.2 & 0.3 & 0.4 & 0.3 \\
\hline${ }^{14} \mathrm{CO}_{2}$ & - & 0.1 & 0.4 & 0.6 & 1.8 & - & 0.1 & 0.2 & 0.2 & 0.6 \\
\hline Bound ${ }^{14} \mathrm{C}$ & 20.4 & 41.2 & 43.8 & 48.8 & 59.2 & 29.7 & 37.0 & 57.9 & 47.6 & 63.4 \\
\hline Total & 91.9 & 94.2 & 63.8 & 69.9 & 73.4 & 93.2 & 82.7 & 84.0 & 69.9 & 88.9 \\
\hline
\end{tabular}

a) $-:<0.1 \%$.

${ }^{14} \mathrm{CO}_{2}$, because $93 \%$ of the radioactivity was precipitated as $\mathrm{Ba}^{14} \mathrm{CO}_{3}$. Evolved ${ }^{14} \mathrm{CO}_{2}$ amounted to 8.0 and $2.3 \%$ of the applied dosage in Kikugawa soil 120 days later and Ushiku soil 180 days later, respectively. The bound ${ }^{14} \mathrm{C}$ increased with time, and the amounts reached 56.1 and $40.7 \%$ of the applied dosage in Kikugawa and Ushiku soils at the end of the experiment, respectively as shown in Fig. 4.

Under the flooded condition, most of the radioactivity in the extracts was derived from unchanged mepanipyrim, the same as that under the upland condition. M-31 was the major degradation product that reached up to 3.8 and $6.8 \%$ of the applied in Kikugawa soil 60 days later and Ushiku soil 120 days later, respectively. M-1, M-4,
M-41, M-6 and M-5 were minor degradation products amounting to $0.1-0.7 \%$ of the applied ${ }^{14} \mathrm{C}$. The amounts of ${ }^{14} \mathrm{CO}_{2}$ were less than $2 \%$ of the applied dosage in both soils. The bound ${ }^{14} \mathrm{C}$ increased with time, and the amounts reached 59.2 and $63.4 \%$ of the applied dosage in Kikugawa and Ushiku soils at the end of the experiment, respectively. The amounts of the bound ${ }^{14} \mathrm{C}$ were larger under the flooded condition than those under the upland condition as shown in Fig. 4.

Under the sterilized conditions, most of the radioactivity in the extracts was derived from unchanged mepanipyrim. More than 10 degradation products including $M-1, M-4, M-41$ and $M-31$ were detected in the organo-soluble fraction by TLC analysis, each amount- 


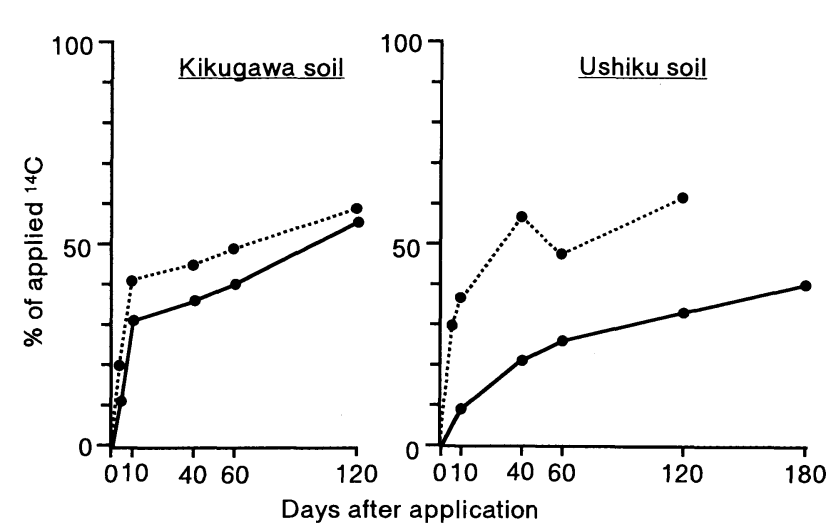

Fig. 4 Changes in amounts of bound ${ }^{14} \mathrm{C}$ in Kikugawa and Ushiku soils.

- : upland condition, $\cdots \cdots \cdot$ : flooded condition.

Table 5 Amounts of $\left[\mathrm{Be}-{ }^{14} \mathrm{C}\right]$ mepanipyrim and its degradation products in Kikugawa and Ushiku soils under the upland condition.

\begin{tabular}{|c|c|c|c|c|}
\hline \multirow{4}{*}{$\begin{array}{c}\text { Fraction } \\
\text { and } \\
\text { degradation } \\
\text { product }\end{array}$} & \multicolumn{4}{|c|}{ \% of applied ${ }^{14} \mathrm{C}$} \\
\hline & \multicolumn{2}{|c|}{ Kikugawa soil } & \multicolumn{2}{|c|}{ Ushiku soil } \\
\hline & \multicolumn{2}{|c|}{ days after application } & \multicolumn{2}{|c|}{ days after application } \\
\hline & 21 & 60 & 60 & 140 \\
\hline Organo-soluble & 68.3 & 40.5 & 76.0 & 64.1 \\
\hline Mepanipyrim & 61.6 & 31.4 & 74.3 & 61.8 \\
\hline M-4 & 0.5 & 0.2 & 0.1 & 0.1 \\
\hline M-6 & 0.1 & 0.1 & 0.1 & 0.1 \\
\hline M-31 & 0.3 & 0.1 & -a) & 0.1 \\
\hline M-39 & 0.4 & 0.4 & 0.1 & 0.1 \\
\hline M-5 & 0.1 & 0.2 & 0.1 & 0.1 \\
\hline Others & 4.2 & 5.3 & 1.1 & 1.6 \\
\hline Origin & 1.1 & 2.7 & 0.3 & 0.3 \\
\hline Water-soluble & 7.1 & 3.0 & 0.3 & 0.6 \\
\hline${ }^{14} \mathrm{CO}_{2}$ & 0.3 & 1.6 & 0.2 & 0.4 \\
\hline Bound ${ }^{14} \mathrm{C}$ & 20.2 & 37.0 & 20.7 & 20.7 \\
\hline Total & 95.8 & 82.1 & 97.1 & 85.7 \\
\hline
\end{tabular}

a) $-:<0.1 \%$

ing to less than $0.2 \%$. M-31 however was detected under the flooded condition only. The bound ${ }^{14} \mathrm{C}$ increased with time, and reached 7.1 and $32.9 \%$ of the applied dosage under the upland and the flooded conditions 120 days later, respectively as shown in Fig. 3.

\section{Degradation Products of $\left[\mathrm{Be}^{-14} \mathrm{C}\right]$ Mepanipyrim in Soils}

The amounts of $\left[\mathrm{Be}^{-14} \mathrm{C}\right]$ mepanipyrim and its degradation products in the soils under the upland and the flooded conditions are listed in Tables 5 and 6, respectively.

Under the upland condition, most of the radioactivity in the extracts was derived from unchanged mepanipyrim. M-4, M-6, M-31, M-39 and M-5 were degradation products amounting to $0.1-0.5 \%$ of the applied dosage.
Table 6 Amounts of $\left[\mathrm{Be}^{-14} \mathrm{C}\right]$ mepanipyrim and its degradation products in Kikugawa and Ushiku soils under the flooded condition.

\begin{tabular}{|c|c|c|c|c|}
\hline \multirow{4}{*}{$\begin{array}{c}\text { Fraction } \\
\text { and } \\
\text { degradation } \\
\text { product }\end{array}$} & \multicolumn{4}{|c|}{$\%$ of applied ${ }^{14} \mathrm{C}$} \\
\hline & \multicolumn{2}{|c|}{ Kikugawa soil } & \multicolumn{2}{|c|}{ Ushiku soil } \\
\hline & days after & plication & days after & application \\
\hline & 60 & 140 & 60 & 140 \\
\hline Organo-soluble & 39.0 & 20.3 & 44.3 & 31.2 \\
\hline Mepanipyrim & 29.9 & 14.4 & 31.7 & 12.8 \\
\hline M-1 & 0.7 & 0.4 & 0.4 & 0.2 \\
\hline M-4 & -a) & - & 0.4 & 0.2 \\
\hline M-6 & 1.2 & 1.0 & 2.6 & 3.8 \\
\hline M-31 & 3.5 & 1.8 & 2.5 & 7.6 \\
\hline M-39 & 0.3 & 0.2 & 0.1 & - \\
\hline M-5 & 0.2 & 0.3 & 0.4 & 0.8 \\
\hline$M-15$ & 0.1 & 0.1 & 0.2 & - \\
\hline Others & 2.5 & 1.5 & 4.7 & 4.4 \\
\hline Origin & 0.7 & 0.6 & 1.3 & 1.3 \\
\hline Water-soluble & 1.4 & 1.2 & 0.3 & 0.3 \\
\hline${ }^{14} \mathrm{CO}_{2}$ & 0.2 & 0.9 & 0.1 & 0.2 \\
\hline Bound ${ }^{14} \mathrm{C}$ & 39.7 & 36.9 & 44.8 & 36.7 \\
\hline Total & 80.3 & 59.9 & 89.4 & 68.4 \\
\hline
\end{tabular}

a) $-:<0.1 \%$.

In addition more than 30 degradation products were detected in the organo-soluble fractions by TLC analysis. Phenol, catechol, resorcinol and hydroquinone, which are likely to be produced by the cleavage of the parent compound between the nitrogen atom and the phenyl group, were not detected in this study. Small amounts of ${ }^{14} \mathrm{CO}_{2}$ were evolved in the both soils. The bound ${ }^{14} \mathrm{C}$ reached to 37.0 and $20.7 \%$ of the applied in Kikugawa and Ushiku soils 60 days after the treatment, respectively.

Under the flooded condition, M-31 was a major degradation product which is the same major one as in the study of $\left[\mathrm{Py}-{ }^{14} \mathrm{C}\right]$ mepanipyrim. The amounts of M-31 were 3.5 and $7.6 \%$ of the applied dosage in Kikugawa soil 60 days later and Ushiku soil 140 days later, respectively. M-1, M-4, M-6, M-39, M-5 and M-15 were minor degradation products. The amount of ${ }^{14} \mathrm{CO}_{2}$ evolved was less than $1 \%$ of the applied dosage in both soils. The bound ${ }^{14} \mathrm{C}$ was 39.7 and $44.8 \%$ of the applied ${ }^{14} \mathrm{C}$ in Kikugawa and Ushiku soils 60 days after the treatment, respectively.

\section{Bound Residues}

Results of the fractionation of the bound residues 40 days after application is shown in Table 7. Radioactivity was mainly distributed in fractions of humic acid and humin in both soils and under both soil conditions. When the fulvic acid fraction was extracted with dichloromethane, mepanipyrim, M-41 and M-31 were detected in the extracts although the amounts were very small. The bound residues formed under the sterilized condition were considerably small, compared with the unsterilized one. The radioactivity was mainly detected 
Table 7 Fractionation of radioactivity in the bound residue from $\left[\mathrm{Py}-{ }^{14} \mathrm{C}\right]$ mepanipyrim 40 days after application.

\begin{tabular}{|c|c|c|c|c|c|c|}
\hline \multirow{4}{*}{$\begin{array}{c}\text { Fraction } \\
\text { and } \\
\text { degradation } \\
\text { product }\end{array}$} & \multicolumn{6}{|c|}{$\%$ of applied ${ }^{14} \mathrm{C}$} \\
\hline & \multicolumn{4}{|c|}{ Unsterilized condition } & \multicolumn{2}{|c|}{ Sterilized condition } \\
\hline & \multicolumn{2}{|c|}{ Upland } & \multicolumn{2}{|c|}{ Flooded } & \multirow{2}{*}{$\frac{\text { Upland }}{\text { Kikugawa }}$} & \multirow{2}{*}{$\frac{\text { Flooded }}{\text { Kikugawa }}$} \\
\hline & Kikugawa & Ushiku & Kikugawa & Ushiku & & \\
\hline Organo-soluble & 0.9 & 0.8 & 1.0 & 1.3 & 0.3 & 1.0 \\
\hline Mepanipyrim & 0.1 & 0.5 & 0.3 & 1.0 & 0.3 & 0.9 \\
\hline$M-41$ & 0.5 & 0.1 & -a) & - & - & - \\
\hline M-31 & - & - & 0.3 & - & - & - \\
\hline Others & 0.3 & 0.2 & 0.4 & 0.3 & - & 0.1 \\
\hline Fluvic acid & 6.3 & 2.3 & 3.1 & 1.2 & 0.5 & 1.1 \\
\hline Humic acid & 18.5 & 5.9 & 17.1 & 13.4 & 1.2 & 6.5 \\
\hline Humin & 11.0 & 12.0 & 22.6 & 42.0 & 2.5 & 5.7 \\
\hline Total & 36.8 & 21.0 & 43.8 & 57.9 & 4.5 & 14.3 \\
\hline
\end{tabular}

a) $-:<0.1 \%$.

in the fractions of humic acid and humin as same as the results of the unsterilized conditions.

\section{DISCUSSION}

The degradation rate and routes of a novel fungicide, mepanipyrim, in soils were studied under the laboratory conditions, using two kinds of ${ }^{14} \mathrm{C}$-preparations labeled separately at the pyrimidine and the benzene rings of the compound.

Under the upland condition, the half-lives ranged from 13 days in Kikugawa soil to 3 months in Ushiku soil. In a separate experiment using two other soils, Nagano volcanic ash soil and Saga alluvial soil, it was found that the half-lives of the compound ranged from 2 to 6 months between them. ${ }^{3}$ Those results suggest that the degradation rate of the compound in soil varies depending on the kinds of the soil.

On the other hand, under the flooded condition, the half-lives resulted in the range between 10 days for Kikugawa soil and 15 days for Ushiku soil and much shorter than those under the upland one, showing that it is more easily broken under the flooded condition than under the upland. It is suggested that mepanipyrim is mainly degraded by soil-microorganisms in soil, because its degradation rate was much retarded in sterilized Kikugawa soil (Fig. 3) compared with unsterilized one. Since mepanipyrim apparently decreased even in the sterilized flooded condition, the non-biological breakdown of the compound may occur under the present aquatic condition.

When the study was separately conducted using the pyrimidine- and the benzene-labeled preparations, M-41 was identified as the major degradation product, while $\mathrm{M}-1, \mathrm{M}-4, \mathrm{M}-31, \mathrm{M}-39, \mathrm{M}-5$ and ${ }^{14} \mathrm{CO}_{2}$ as minor degradation products, under the upland condition, and M-31 was identified as the major degradation product, while $\mathrm{M}-1$, M-4, M-41, M-6, M-39, M-5 and M-15 as other degrada- tion products, under the flooded condition. As shown above, lots of degradation products common in both preparations were detected, except M-41 which was detected in the pyrimidine-preparation only. The proposed degradation pathways of mepanipyrim are shown in Fig. 5.

Mepanipyrim has a unique structure that a benzene ring and a pyrimidine ring are combined through an amine and that a propynyl group is substituted at the 6-position of the latter ring as a substituent. The compound presumably undergoes the following two reactions in its degradation: (1) elimination of the phenyl group into M-41, and (2) addition of water molecule into the propynyl unsaturated bond, followed by reduction. It is considered that the former reaction is dominant in soil under the upland condition. The elimination converts the parent compound into M-41. The authors have no exact information about the mechanism of the elimination, except that it is presumed to be a kind of dealkylation reactions common to amino compounds, ${ }^{6,7)}$ not a hydrolytic one, because no phenols, likely to be formed in the reaction, were detected in the experiment.

The reaction 2 is accompanied with a subsequent reduction of the resulting product, M-6. Probably the reaction is prevalent in soil under the flooded condition, compared with the upland one, considering the amount formed under the each condition. The conversion of a triple bond to the corresponding ketone by addition of water molecule has been biologically observed in mammals as one of common metabolic reactions. ${ }^{8,9)}$ However, this reaction has little been reported in the degradation of chemicals in soils. On the other hand, the successive reduction of ketones to corresponding alcohols has been widely observed in the degradation of chemicals in organisms, ${ }^{7)}$ as shown in the biotransformation of 1-(4hydroxy-3-methoxyphenyl)-2-propanone ${ }^{10)}$ and warfarin, ${ }^{11}$ which have the same propynyl moiety as 


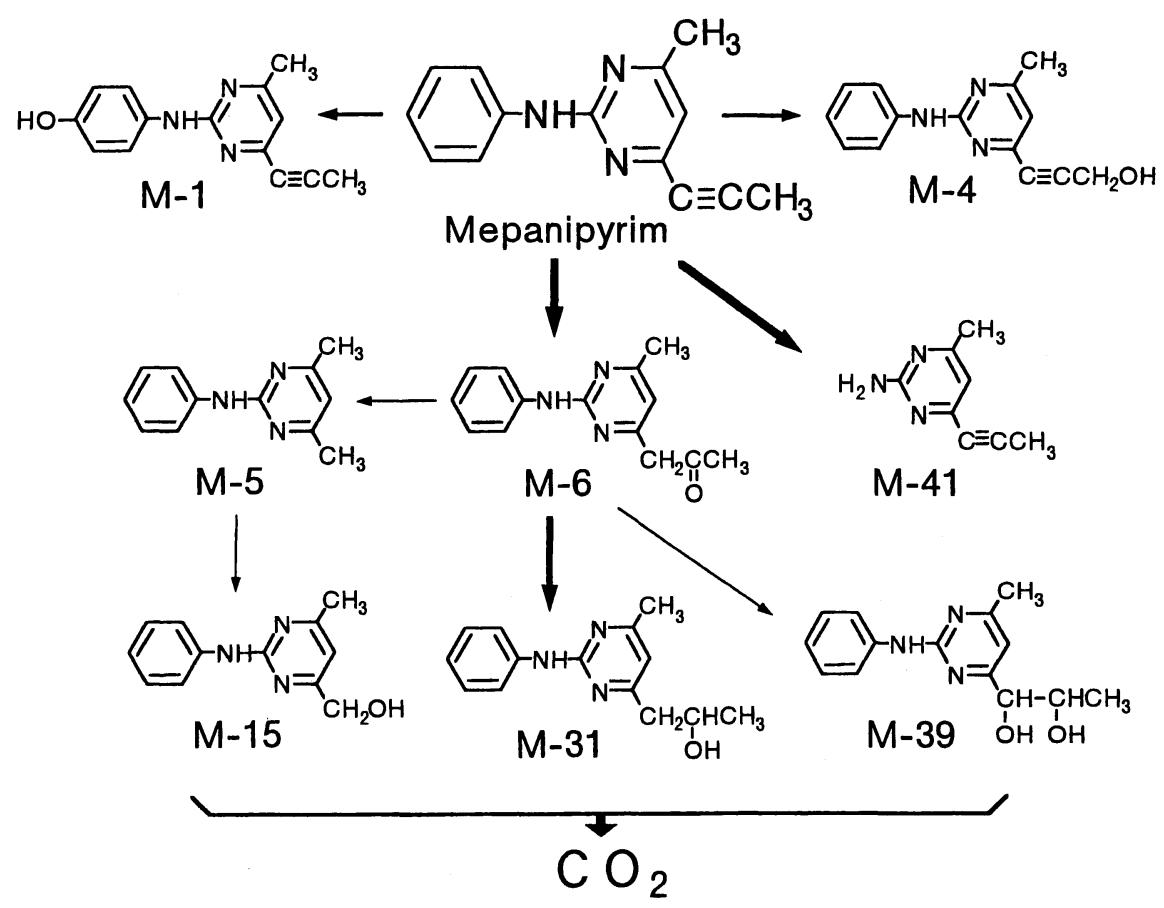

Fig. 5 Proposed degradation pathways of mepanipyrim in soil. Major pathways are expressed as $\rightarrow$.

mepanipyrim in the partial structures. It is presumed that the formation of M-31 via M-6 takes place even non-biologically because it was formed even in the sterilized soil, although the amount formed was very small, while it was formed in a large amount in the unsterilized soil. These rapid changes involving the propynyl moiety cause the rapid degradation of the parent compound in soil under the flooded condition, compared with the upland one. Besides, hydroxylation occurs at the 4position of the benzene ring ${ }^{7)}$ and/or the terminal carbon of the propynyl group. ${ }^{12)}$ Lots of degradation products, other than the above-mentioned ones, in small amounts were detected from both ${ }^{14} \mathrm{C}$-preparations. So, it is considered that the identified products are further degraded at the various positions resulting in lots of degradation products.

The bound ${ }^{14} \mathrm{C}$ activity was very small in the sterilized soil under the upland condition where mepanipyrim was slowly degraded (Fig. 3). On the other hand, the bound residues increased under both unsterilized conditions and sterilized flooded condition where the parent compound was degraded. It is assumed that the bound ${ }^{14} \mathrm{C}$ activity was mainly due to the degradation products. It is clarified that the bound ${ }^{14} \mathrm{C}$ was mainly fractionated into the humic acid and the humin fractions. It is also added that both rings of the parent compound are finally mineralized, more or less rapidly, because ${ }^{14} \mathrm{CO}_{2}$ was given from both ${ }^{14} \mathrm{C}$-preparations and its amount increased gradually with the elapse of time.

\section{ACKNOWLEDGMENTS}

Authors express many thanks to K-I Chemical Research Institute Co., Ltd. for the supply of the authentic standard compounds.

\section{REFERENCES}

1) S. Maeno, I. Miura, K. Masuda \& T. Nagata: Synopses ; Brighton Crop Prot. Conf. Pests and Dis. 1990 2, 415 (1990)

2) I. Miura, T. Kamakura, S. Maeno, T. Nagata, S. Hayashi \& I. Yamaguchi : J. Pesticide Sci. 19, 103 (1994)

3) M. Ikeda, T. Oishi, Y. Asano \& K. Ishikawa : Synopses ; 17th Conf. Pesticide Sci. Soc. Jpn., Fukuoka, p. 124, 1992 (in Japanese)

4) M. Ikeda, T. Unai \& C. Tomizawa : J. Pesticide Sci. 11, 85 (1986)

5) S. Mitsui \& A. Kurihara : J. Sci. Soil Manure Jpn. 11, 439 (1958)

6) S. U. Khan : "Pesticides in the Soil Environment," Elsevier Scientific Publishing Co., New York, pp. 119-162, 1980

7) T. Shishido \& H. Ohkawa : "Methods in Pesticide Science," ed. by J. Fukami, Y. Uesugi, K. Ishizuka \& T. Tomizawa, Vol. 4, Soft Science Inc., Tokyo, pp. 3-19, 1981 (in Japanese)

8) K. Shiba, N. Kakuta, H. Kaneko, I. Nakatsuka, A. Yoshitake, H. Yamada \& J. Miyamoto: J. Pesticide Sci. 13, 557 (1988)

9) J. E. Casida \& L. O. Ruzo: Pestic. Sci. 11, 257 (1980)

10) J. J. Liebert : Xenobiotica 23, 693 (1993)

11) R. J. Lewis \& W. F. Trager : J. Clin. Invest. 49, 907 (1970)

12) P. Lahteenmaki, O. Heikinheimo, H. Croxatto, I. Spitz, D. Shoupe, L. Birgerson \& T. Luukkainen: J. Steroid Bio- 
chem. 27, 859 (1987)

要 約

\section{殺菌剤メパニピリムの土壤における分解}

池田光政，浅野 讓，前田嘉洋，遊佐義男 メパニピリムのピリミジン環 4 位またはベンゼン環を ${ }^{14} \mathrm{C}$ で標識した化合物を用い，土壌中での分解を室内試験 で調べた. 2 種類の土堙にメパニピリムを $0.4 \mathrm{ppm} の$ 割合 で添加し畑条件で培養すると，その半減期は 2 週間から 3 力月間であった. 主な分解経路は $N$-脱フェニル化であり,
他にプロピニル基やベンゼン環が水酸化をうけ，生成した 分解物はさらに ${ }^{14} \mathrm{CO}_{2}$ まで分解したり bound ${ }^{14} \mathrm{C}$ を形成し た. 湛水条件では，畑条件に比べ分解が速く，また，bound ${ }^{14} \mathrm{C}$ も多かった. 湛水条件ではプロピニル基が種々の変換 をうけることが主な分解経路であった.滅菌土壤において、 畑条件ではメパニピリムがほとんど分解しなかったことか ら分解には主に微生物の関与が，また、湛水条件では緩や かに分解したことから非生物的分解も関与することが示唆 された。 